\title{
De inzet van niet-direct inzetbaar arbeidsaanbod bij knelpunten op de arbeidsmarkt
}

Citation for published version (APA):

de Grip, A., Vlasblom, J. D., \& Jacobs, A. (1999). De inzet van niet-direct inzetbaar arbeidsaanbod bij knelpunten op de arbeidsmarkt. Researchcentrum voor Onderwijs en Arbeidsmarkt, Faculteit der Economische Wetenschappen. ROA Working Papers No. 2 https://doi.org/10.26481/umarow.1999002

Document status and date:

Published: 01/01/1999

DOI:

10.26481/umarow.1999002

Document Version:

Publisher's PDF, also known as Version of record

\section{Please check the document version of this publication:}

- A submitted manuscript is the version of the article upon submission and before peer-review. There can be important differences between the submitted version and the official published version of record.

People interested in the research are advised to contact the author for the final version of the publication, or visit the DOI to the publisher's website.

- The final author version and the galley proof are versions of the publication after peer review.

- The final published version features the final layout of the paper including the volume, issue and page numbers.

Link to publication

\footnotetext{
General rights rights.

- You may freely distribute the URL identifying the publication in the public portal. please follow below link for the End User Agreement:

www.umlib.nl/taverne-license

Take down policy

If you believe that this document breaches copyright please contact us at:

repository@maastrichtuniversity.nl

providing details and we will investigate your claim.
}

Copyright and moral rights for the publications made accessible in the public portal are retained by the authors and/or other copyright owners and it is a condition of accessing publications that users recognise and abide by the legal requirements associated with these

- Users may download and print one copy of any publication from the public portal for the purpose of private study or research.

- You may not further distribute the material or use it for any profit-making activity or commercial gain

If the publication is distributed under the terms of Article $25 \mathrm{fa}$ of the Dutch Copyright Act, indicated by the "Taverne" license above, 


\title{
De inzet van niet-direct inzetbaar arbeidsaanbod bij knelpunten op de arbeidsmarkt
}

\author{
ROA-W-1999/2 \\ Andries de Grip, Ank Jacobs en Jan Dirk Vlasblom
}

Researchcentrum voor Onderwijs en Arbeidsmarkt

Faculteit der Economische Wetenschappen en Bedrijfskunde Universiteit Maastricht

Maastricht, mei 1999 
Inhoudsopgave

Bladzijde

Voorwoord

1 Inleiding

2 Knelpunten op de arbeidsmarkt 2

2.1 Inleiding 2

2.2 Verwachte knelpunten naar opleidingssector $\quad 2$

$\begin{array}{ll}2.3 \text { Mogelijke aanpassingsprocessen van werkgevers } & 6\end{array}$

3 De beschikbaarheid en inzetbaarheid van additioneel aanbod 9

3.1 Inleiding 9

3.2 Kwalificatieveroudering en scholingsinspanning 9

$\begin{array}{lr}3.3 \text { Het additionele aanbod nader toegelicht } & 10\end{array}$

$\begin{array}{ll}3.4 \text { Voorkeursvolgorde van de werkgever } & 15\end{array}$

4 Knelpunten op de arbeidsmarkt in ruime zin 17

$\begin{array}{ll}4.1 \text { Inleiding } & 17\end{array}$

4.2 Verwachte knelpunten in ruime zin $\quad 17$

4.3 Indicatie van de vereiste vaardigheden 19

4.4 Scholingsinspanningen 23

5 Samenvatting en conclusies $\quad 25$

$\begin{array}{ll}\text { Literatuur } & 27\end{array}$ 


\section{Voorwoord}

Dit werkdocument maakt deel uit van het Project Onderwijs-Arbeidsmarkt (POA). Dit project wordt gefinancierd door het Ministerie van Onderwijs, Cultuur en Wetenschappen, Arbeidsvoorziening Facilitair Bedrijf, het LDC Expertisecentrum voor Loopbaanvraagstukken en het Ministerie van Landbouw, Natuurbeheer en Visserij.

De komende jaren wordt voor een groot aantal opleidingen knelpunten in de personeelsvoorziening verwacht. Om deze tekorten het hoofd te kunnen bieden is het belangrijk dat werkgevers in toenemende mate op zoek gaan naar additioneel arbeidsaanbod vanuit groepen die op dit moment niet actief zijn op de arbeidsmarkt. Het is daarbij van belang om inzicht te hebben in hoeverre uit deze groepen mensen kunnen worden geworven, die ingezet kunnen worden om deze tekorten te verminderen. Dergelijke arbeidsmarktinformatie is vooralsnog in beperkte mate voorhanden. In dit werkdocument wordt getracht een overzicht te geven van de mogelijkheden om dit arbeidspotentieel aan te wenden en van de mogelijke processen die hierbij een rol kunnen spelen. 


\section{Inleiding}

De arbeidsmarkt naar opleiding en beroep tot 2002 laat ontwikkelingen zien die wijzen op een sterke omslag in de arbeidsmarktsituatie. De komende jaren wordt voor een groot aantal opleidingstypen knelpunten in de personeelsvoorziening verwacht. Deze ontwikkeling zal, naar het zich nu laat aanzien, ook enige tijd aanhouden. Borghans e.a. (1998) laten zien dat voor de periode tot 2007 de verwachte knelpunten in de personeelsvoorziening niet kleiner van omvang zijn dan de knelpunten die op de kortere termijn verwacht worden. De omslag op de arbeidsmarkt in de tweede helft van de jaren negentig betekent aan de ene kant een verbetering van de arbeidsmarktsperspectieven voor veel schoolverlaters. Aan de andere kant betekent deze omslag dat werkgevers de komende jaren in toenemende mate moeite zullen krijgen om in hun personeelsbehoefte te voorzien door het aantrekken van schoolverlaters, terwijl ook het aanbod van direct inzetbare werklozen sterk is gekrompen. Het gevolg daarvan is dat werkgevers in toenemende mate op zoek moeten naar 'additioneel arbeidsaanbod' vanuit groepen die op dit momentnietactiefzijnop dearbeidsmarkt:schoolverlaters metdeverkeerde opleidingsachtergrond, langdurig werklozen, gedeeltelijk arbeidsongeschikten en andere niet-participerenden op de arbeidsmarkt.

Vanuit zowel werkgevers- als beleidsoptiek is het van groot belang om inzicht te hebben in de vraag in hoeverre dit additionele aanbod een rol kan spelen bij het verminderen van de knelpunten in de personeelsvoorziening. Daarbij is het belangrijk om te weten in hoeverre er in deze groepen mensen aanwezig zijn met de juiste opleidingsachtergrond. Bij personen die zich lang buiten het arbeidsproces hebben bevonden, of die een opleidingsachtergrond hebben die onvoldoende aansluit op de eisen die de arbeidsmarkt tegenwoordig stelt, zullen echter vaak extra inspanningen noodzakelijk zijn om een goed functioneren op de arbeidsmarkt mogelijk te maken. Hierbij kan met name gedacht worden aan vormen van om- of bijscholing. Vanuit het oogpunt van het beleid is er nog een tweede aspect dat van belang is. Een krappe arbeidsmarkt kan namelijk de positie van diverse doelgroepen van arbeidsmarktbeleid (langdurig werklozen, allochtonen, arbeidsgehandicapten) aanzienlijk versterken. Vanuit het individuele perspectief van iemand die niet actief is, is het belangrijk om inzicht te krijgen in de mogelijkheden die hij of zij krijgt als gevolg van de toenemende krapte op de arbeidsmarkt. Deze mogelijkheden zijn echter wel, waarschijnlijk veel meer dan bij schoolverlaters, afhankelijk van personeelskenmerken zoals leeftijd, ervaring en eventuele belemmeringen om te gaan werken.

Dergelijke arbeidsmarktinformatie is vooralsnog slechts in beperkte mate voorhanden. Daarom wordt in deze studie een eerste aanzet gegeven om hierin te voorzien. In de eerste plaats wordt getracht inzicht te verkrijgen in de knelpunten die de komende jaren zullen gaan optreden. Vervolgens wordt aandacht geschonken aan de wijze waarop werkgevers met deze knelpunten om zullen gaan. Een van de manieren is dat zij mensen zullen gaan aannemen die in eerste instantie niet als relevant arbeidsaanbod gezien worden: jongeren die het initieel onderwijs verlaten met een opleidingsachtergrond met een matig tot slecht perspectief (met name de laaggeschoolden), langdurig werklozen en niet-participerenden. De gedachte is dat een deel van dit (potentiële) aanbod door additionele onderwijs- of scholingsinspanningen in aanmerking 
kan komen voor de baanopeningen die niet door het direct inzetbare arbeidsaanbod kunnen worden opgevuld. Deze studie zal proberen inzicht te geven in de omvang en samenstelling van dit (mogelijke) additionele arbeidsaanbod en de mate van scholing die zij nodig zullen hebben. Deze informatie kan vervolgens worden gebruikt om niet alleen de knelpunten in de personeelsvoorziening in enge zin (d.w.z het vraagoverschot naar schoolverlaters en kortdurig werklozen met de juiste opleidingsachtergrond), maar ook de knelpunten in ruime zin in kaart te brengen.

De opbouw van dit werkdocument is als volgt. Allereerst zal in hoofdstuk 2 een kort overzicht gegeven worden van de te verwachten knelpunten in de personeelsvoorziening tot 2002. Ook zal in dit hoofdstuk aangegeven worden op welke manieren werkgevers met deze knelpunten om kunnen gaan. Vervolgens zal in hoofdstuk 3 worden stilgestaan bij de beschikbaarheid en inzetbaarheid van het additionele arbeidsaanbod. Hierbij komen zaken als kwalificatieveroudering en de noodzakelijke scholingsinspanningen aan bod. In hoofdstuk 4 wordt op basis van de informatie over de personeelstekorten en de opleidingsachtergrond van het additionele arbeidsaanbod nagegaan in hoeverre de knelpunten door dit aanbod opgelost kunnen worden. Hierbij wordt ook aandacht geschonken aan de benodigde inspanningen om dit niet-direct inzetbare aanbod een kans te bieden op de arbeidsmarkt. Omdat niet alle tekorten op deze manier vervuld kunnen worden, wordt er in dit hoofdstuk ook een aanzet gegeven om na te gaan in hoeverre werkgevers de mogelijkheid hebben om uit te wijken naar aanbod met een andere opleidingsachtergrond. Ten slotte wordt in hoofdstuk 5 een samenvatting van de belangrijkste bevindingen gegeven en een aantal concluderende opmerkingen gemaakt.

\section{Knelpunten op de arbeidsmarkt}

\subsection{Inleiding}

Als uitgangspunt voor de vraag in hoeverre werkgevers hun personeel moeten en kunnen gaan werven uit het niet direct inzetbare arbeidsaanbod, zullen we eerst een overzicht moeten krijgen van de tekorten die verwacht worden. In paragraaf 2.2 wordt dit overzicht gegeven. De cijfers in deze paragraaf zijn gebaseerd op prognoses tot 2002, de meest recente prognoses in het kader van het Project Onderwijs-Arbeidsmarkt (POA). Daarna wordt in paragraaf 2.3 stilgestaan bij de vraag in hoeverre werkgevers mogelijkheden hebben om in het geval van tekorten zich aan te passen om zo de tekorten het hoofd te bieden. De informatie uit deze beide paragrafen zal dienen om in hoofdstuk 3 na te gaan hoe de diverse groepen uit het additionele arbeidsaanbod inzetbaar zijn.

\subsection{Verwachte knelpunten naar opleidingssector}

In de arbeidsmarktprognoses voor de diverse beroepen en opleidingen wordt aan de vraagzijde van de arbeidsmarkt een tweetal componenten onderscheiden. Enerzijds de uitbreidingsvraag en anderzijds de vervangingsvraag. De uitbreidingsvraag is de vraag naar nieuwe arbeidskrachten 
die ontstaat door groei van de werkgelegenheid. Als er sprake is van een werkgelegenheidsdaling, is de uitbreidingsvraag negatief. De vervangingsvraag is de vraag naar nieuwe arbeidskrachten die ontstaat doordat de arbeidsplaatsen van werkenden die met pensioen gaan, arbeidsongeschikt worden of zich (tijdelijk) terugtrekken van de arbeidsmarkt opnieuw moeten worden opgevuld. Vertrek van werkenden dat niet leidt tot vraag naar nieuwkomers wordt derhalve niet meegeteld ${ }^{1}$.

Werkgevers hebben in principe een vacature voor een bepaalde functie. De prognoses voor de uitbreidingsvraag worden daarom in eerste instantie gemaakt per beroepsgroep. Vervolgens worden deze prognoses opbasis van de binnen de diverse beroepsgroepen gevraagde opleidingen vertaald in vraagprognoses voor de verschillende opleidingstypen. De vervangingsvraag kan zowel voor opleidingstypen als voor beroepen bepaald worden. Derhalve kan de vraag naar arbeid zowel per opleidingstype als per beroepsgroep worden bepaald. De som van vervangingsvraag en de (positieve) uitbreidingsvraag geeft het aantal baanopeningen voor nieuwkomers op de arbeidsmarkt.

Tegenover de baanopeningen (de vraag) staan de prognoses van het arbeidsaanbod. Er wordt verondersteld dat werkgevers deze baanopeningen in eerste instantie vullen methet directinzetbare arbeidsaanbod, dat wil zeggen schoolverlaters of kortdurig werklozen met de juiste opleidingsachtergrond $^{2}$. Deze twee groepen vormen tezamen met de gediplomeerden van het niet-initieel onderwijs het aanbod dat in de prognoses betrokken wordt. Vraag en aanbod kunnen tegenover elkaar geplaatst worden. Dit levert een prognose op voor de arbeidsmarktperspectieven van schoolverlaters en voor de knelpunten in de personeelsvoorziening voor de werkgevers. De prognoses voor de aantallen schoolverlaters worden alleen per opleidingstype gemaakt. Het is immers moeilijk om het arbeidsaanbod op een betrouwbare manier te specificeren per beroep. Daarom zijn de knelpunten in de personeelsvoorziening, op basis van een vraag-aanbod confrontatie, alleen in beeld gebracht per opleidingstype.

\section{Passieve substitutie versus inzet additionele arbeidsaanbod}

De bovenstaande methodiek gaat er van uit dat pas zodra het direct inzetbare arbeidsaanbod, om welke reden dan ook, niet voldoende is, werkgevers zullen omzien naar andere manieren om in hun personeelsbehoeften te voorzien. Bij knelpunten in de personeelsvoorziening door een tekortschietend aanbod van direct inzetbare werkzoekenden, zullen werkgevers proberen hun baanopeningen op een andere manier te vervullen. Hierdoor zal onder andere hun vraag verschuiven naar schoolverlaters met een andere opleidingsachtergrond. Dit levert een vraagverschuiving op als gevolg van de ex-ante verwachte knelpunten. Deze zogenaamde passieve substitutievraag geeft voor een bepaald opleidingstype aan hoe de vraag wijzigt als gevolg van

1. Bij de berekening van deze vervangingsvraag wordt verondersteld dat tijdens de prognoseperiode geen aanpassingsprocessen zullen optreden als gevolg van de verwachte arbeidsmarktsituatie. Dit betekent dat de inzet van het additionele arbeidsaanbod tijdens de prognoseperiode als een ex post aanpassing moet worden geïnterpreteerd.

2. Deze is gebaseerd op de netto veranderingen in de participatie voor een bepaald leeftijdscohort, dat wil zeggen de bruto-uitstroom minus de bruto-instroom van herintreders. 
de verwachte knelpunten in de personeelsvoorziening bij verwante opleidingstypen (zie De Grip, Borghans en Smits, 1998).

Ook bij het bepalen van de substitutievraag wordt verondersteld dat werkgevers zich bij knelpunten in de personeelsvoorziening in eerste instantie zullen richten op schoolverlaters, desnoods met een "verkeerde opleidingsachtergrond". Het weergeven van de knelpunten inclusief de substitutievraag gaat dus voorbij aan het feit dat werkgevers hun vraag naar arbeid ook op een andere wijze, bijvoorbeeld vanuit het additionele arbeidsaanbod, kunnen vervullen. Omdat juist daar niets over bekend is, zullen we hier, in tegenstelling tot de in De arbeidsmarkt naar opleiding en beroep tot 2002 gepubliceerde prognoses de ex-ante tekorten laten zien zonder het effect van de passieve substitutievraag.

\section{Negatieve uitbreidingsvraag}

Een veronderstelling die bij de prognoses in het kader van het POA-project wordt gemaakt is dat het arbeidsmarktperspectief van schoolverlaters niet beïnvloed wordt door een eventuele negatieve uitbreidingsvraag voor het desbetreffende opleidingstype. Dat wil zeggen dat de perspectieven van schoolverlaters met een bepaald opleidingstype niet minder worden, ook al komen er elders als gevolg van werkgelegenheidskrimp mensen met dezelfde opleidingsachtergrond op straat te staan. Er wordt dan in feite aangenomen dat de werkzoekenden die als gevolg van werkgelegenheidskrimp in bepaalde sectoren en beroepen hun baan zullen verliezen geen concurrentie vormen voor de schoolverlaters. Bij de indicator voor de toekomstige knelpunten in de personeelsvoorziening (ITKP) wordt daarentegen wel rekening gehouden met deze negatieve uitbreidingsvraag, vanuit de veronderstelling dat in geval van dergelijke knelpunten het voor werkgevers aantrekkelijk is deze mensen aan te trekken c.q. ondanks de werkgelegenheidskrimp toch in dienst te houden. Hier ligt dan wel de impliciete veronderstelling aan ten grondslag dat de inzetbaarheid van deze groepen groter is dan die van het alternatieve aanbod. Het extra aanbod als gevolg van een eventuele negatieve uitbreidingsvraag zal daarom ook hier bij het in kaart brengen van de knelpunten in de personeelsvoorziening worden meegenomen.

In tabel 2.1 staat per opleidingssector aangegeven hoe groot de tekorten en de overschotten zijn. Omwille van de presenteerbaarheid worden de knelpunten in de personeelsvoorziening hier op een hoger aggregatieniveau gepresenteerd. Uitgangspunt hierbij zijn de prognoses die gepubliceerd zijn in De arbeidsmarkt naar opleiding en beroep tot 2002 (ROA, 1997a en 1997b). De tekorten en overschotten zijn gesommeerd over de opleidingstypen die tot de desbetreffende opleidingssector worden gerekend. Daarmee wordt weergegeven hoe groot het netto tekort of overschot van een opleidingssector is. Eerst zijn alle tekorten en alle overschotten opgeteld. Vervolgens zijn de totaaltellingen gesaldeerd.

Tabel 2.1

Verwachte aanbodtekorten per opleidingssector in 2002 
Basisonderwijs

VBO/MAVO

VBO Landbouw en natuurlijke omgeving

VBO Techniek

VBO Economie

VBO Verzorgend

VBO Openbare orde en veiligheid

VBO Overig

HAVO/VWO

MBO/LLW Landbouw en natuurlijke omgeving

MBO/LLW Techniek

MBO/LLW Dienstverlening en gezondheidszorg

$\mathrm{MBO} / \mathrm{LLW}$ Economie

MBO Openbare orde en veiligheid

MBO/LLW Overig

HBO Onderwijs en tolk en vertaler

HBO Landbouw

HBO Techniek

HBO Paramedisch

HBO Economie

HBO Sociaal-cultureel

HBO Kunst

HBO Openbare orde en veiligheid

HBO Overig

WO Letteren en theologie

WO Landbouw en milieukunde

WO Techniek

WO Medisch

WO Economie

WO Sociaal-cultureel

WO Kunst

WO Overig

Overig

Totaal
45.000

$80.500 \quad 125.500$

2.500

50.500

0
2.500

1.500

3.000

0
17.000

110.500

62.500

56.000

13.500

7.000

50.500

2.000

31.000

19.500

18.500

15.500

4.000

500

12.500

4.000

10.500

4.500

23.000

6.500

0
7.000

3.500

578.500
26.500

0

25.000

6.500

0

0

0
1.500

0

1.500

6.000

0

0

0

0
1.000
500

500

2.000

0

1.000

0

0

150.000

$\begin{array}{rr}0 & ! 40.000 \\ 12.500 & 10.000 \\ 24.000 & ! 16.500 \\ 15.500 & 36.000 \\ 2.000 & ! 500 \\ 0 & ! 1.500 \\ 0 & ! 3.000\end{array}$

$\begin{array}{rr}0 & 26.500 \\ 0 & ! 17.000 \\ 1.000 & ! 10.600 \\ 0 & ! 37.500 \\ 5.500 & ! 44.000 \\ 0 & ! 13.500 \\ 0 & ! 7.000\end{array}$

$3.000 \quad 477.000$

! 500

! 31.000

! 19.500

$0 ! 17.500$

$0 \quad ! 9.000$

$0 \quad ! 4.000$

$0 \quad ! 500$

$0 \quad ! 12.500$

$$
1.000 \quad 3.000
$$

$0 \quad 1.000$

$0 ! 10.000$

$0 ! 4.000$

$0 ! 20.500$

$1.500 \quad ! 5.000$

$0 \quad 1.000$

$0 \quad ! 7.000$

$0 \quad ! 3.500$

$146.500 \quad ! 282.000$

a) Een positief saldo is een aanbodoverschot

Bron: ROA

Het gelijktijdig voorkomen van tekorten en overschotten geeft aan dat er ook binnen de opleidingssector sprake is van een mismatch naar opleidingstype. Het saldo geeft daarentegen aan of er binnen de sector sprake is van een netto tekort of overschot. Om aan te geven in welke sectoren de ex-ante tekorten aan direct beschikbaar arbeidsaanbod verzacht zullen worden door het vóórkomen van negatieve uitbreidingsvraag, is dit aanbod (in feite de tijdens de prognoseperiode ontstane kortdurige werkloosheid) in een aparte kolom in de tabel aangegeven. 
De eerste kolom van tabel 2.1 laat zien dat er voor vrijwel alle opleidingssectoren in 2002 een tekort aan arbeidskrachten wordt verwacht. Er zijn maar een paar uitzonderingen: het Basisonderwijs, de sector VBO economie, HAVO/VWO en een tweetal kleine sectoren in het WO, namelijk Landbouw en Kunsten. Voor deze opleidingssectoren wordt een aanbodoverschot verwacht. Daarnaast blijkt uit de tweede kolom van de tabel dat er, hoewel er sprake is van een netto vraagoverschot, er binnen de verschillende opleidingssectoren wel degelijk opleidingen voorkomen met een aanbodoverschot: binnen deze sectoren bestaat er derhalve een mismatch naar richting. Hiervan is sprake bij VBO technieken een aantal MBO sectoren, waarvan MBO/LLW Dienstverlening de belangrijkste is. In totaal is er een vraagoverschot voor ongeveer 578.500 mensen, terwijl er daarnaast een groep van 150.000 schoolverlaters is met een vanuit arbeidsmarktoogpunt verkeerd opleidingstype. Dit betekent dat er een netto tekort aan arbeidskrachten is van 428.500 mensen.

Wordt er vervolgens gekeken in hoeverre de knelpunten verminderd kunnen worden door het aantrekken van mensen die als gevolg van de werkgelegenheidskrimp hun baan zullen verliezen, dan blijkt dit vooral aan de onderkant van de arbeidsmarkt grote invloed te hebben. Het toch al grote overschot aan ongeschoolden neemt toe, terwijl de tekorten op VBO-niveau voor een deel verdwijnen en de bestaande overschotten op dit niveau toenemen. Op de hogere opleidingsniveau'sspeeltwerkgelegenheidskrimpgeenrolvanbetekenis. Doordezeonevenwichtige verdeling van deze werkgelegenheidskrimp ontstaat hetzelfde beeld als eerder is geconstateerd in Borghans e.a. (1998), namelijk dat er in sommige opleidingssectoren op de lagere niveau's sprake is van een overschot, terwijl er op de hogere niveau's sprake is van een tekort ${ }^{3}$.

\subsection{Mogelijke aanpassingsprocessen van werkgevers}

In de vorige paragraaf werd duidelijk dat er de komende jaren sprake zal zijn van kwalitatieve en kwantitatieve discrepanties op de arbeidsmarkt. Werkgevers moeten echter hun vacatures vervullen en zullen gaan zoeken naar mogelijkheden om de verwachte tekorten het hoofd te bieden. Demanierwaarop dat gebeurt, bepaaltwelke personen uit deverschillende aanbodgroepen aangenomen zullen worden. Merk op dat het een gevolg is van onze aannames dat er uitsluitend mogelijkheden zijn voor het niet-direct inzetbare arbeidsaanbod als er een (ex-ante) vraagoverschot op de arbeidsmarkt verwacht wordt. Indien er geen sprake is van een vraagoverschot, kunnen werkgevers namelijk volledig in hun personeelsbehoeften voorzien door het aantrekken van schoolverlaters en de direct inzetbare (kortdurig) werklozen.

De verschillende aanpassingsprocessen die zich kunnen voordoen worden in schema 2.1 op een sterk vereenvoudigde manier schematisch weergegeven (zie ook Borghans, De Grip en

3. Er is wel een verschil met het rapport Toekomstverkenning arbeidsmarkt en scholing tot 2007 (Borghans e.a., 1998). In dit rapport zijn namelijk de tekorten weergegeven inclusief de substitutievraag, hier zijn ze weergegeven exclusief de substitutievraag. Dit heeft als gevolg dat er in Borghans e.a. twee soorten mismatches zijn voorspeld, namelijk tussen de vijf opleidingsniveau's en binnen de vijf opleidingsniveaus. De mismatch tussen de opleidingsniveau's is echter voor een groot deel toe te schrijven aan de substitutievraag en is dus in deze tabel veel beperkter van omvang. 
Van Smoorenburg, 1998). Een eerste aanpassingsproces is dat werkgevers overgaan tot het aannemen van iemand die reeds werkzaam is. Ze kunnen proberen om via hogere beloningen, betere secundaire arbeidsvoorwaarden of intensievere wervingscampagnes de aantrekkingskracht van het bedrijf te vergroten. Hierdoor zijn ze wellicht in staat om werknemers weg te trekken bijandere bedrijven. Het aantrekken van werknemers die reeds elders werkzaam zijn lost weliswaar het probleem voor de individuele werkgever op, maar niet voor de arbeidsmarkt als geheel. Bovendien kan door het bieden van steeds hogere beloningen het gevaar ontstaan van een oververhitting van de economie in de vorm van een "loonexplosie". Om een dergelijke oververhitting te voorkomen is het nodig dat werkgevers hun baanopeningen proberen te vervullen door personeel te werven uit de groepen die aan de zijlijn van de arbeidsmarkt staan.

De andere mogelijkheid is dat er mensen werkzaam zijn in een zogenaamd "uitwijkberoep" maar terug willen naar het beroep waar ze eigenlijk werkzaam hadden willen zijn zodra daar mogelijkheden voor ontstaan (zie ook De Grip, Borghans en Smits, 1998). Dit lost wel het probleem voor de individuele werkgever op, maar verplaatst het probleem mogelijk naar een ander arbeidsmarktsegment, omdat er een vacatureketen zal ontstaan. Omdat de nieuwe vacature op het uitwijksegment anders van aard is dan de oorspronkelijke, kan het voor de tweede werkgever misschien gemakkelijker zijn de vraag te verleggen naar een ander opleidingstype dan de vereiste opleidingsachtergrond voor de "oorspronkelijke vacature". Via dit soort mechanismen kan de vraag van het ene naar het andere opleidingstype verschuiven. Gevolg is wellicht dat de uiteindelijke baanopening voor iemand uit het additionele aanbod op een ander opleidingsniveau en/of -richting betrekking heeft dan de initiële vacature.

Vier aanpassingsprocessen die in het schema genoemd worden, reorganisatie van het productieproces, stimuleren van overwerk of reductie van de productie worden hier verder buiten beschouwing gelaten, omdat ze - behoudens de functiesplitsing - geen effect hebben op de vraag naar niet direct inzetbare arbeidskrachten.

Bij- en omscholing van eigen personeel heeft uitsluitend een gunstig effect op de omvang van de knelpunten als het mogelijk is om de plek die vrij komt doordat een eigen werknemer omof bijgeschoold wordt, bezet kan worden door iemand met opleidingsachtergrond waarvoor er voldoende (niet direct inzetbaar) arbeidsaanbod is. Dit is in feite ook een voorbeeld van arbeidsmarktmobiliteit die een verschuiving van de baanopening van het ene naar het andere opleidingstype tot gevolg heeft. Bij- en omscholing van nieuw personeel met een verkeerde of te lage opleidingsachtergrond is een aanpassing die hiermee vergelijkbaar is. Voor al deze genoemde aanpassingen kunnen werkgevers iemand aannemen met een enigszins verwante opleidingsachtergrond en deze omscholen, maar bijvoorbeeld ook een langdurig werkloze of een herintreder met de juiste opleidingsachtergrond die door middel van een "opfriscursus" of een zwaarder opleidingstraject wordt bijgeschoold. 
Schema 2.1

Mogelijke aanpassingsprocessen bij knelpunten in de personeelsvoorziening

Mogelijkheden

Doelgroepen

Schoolverlaters Langdurig werklozen Niet-participerenden

Rekruteren werknemer

die elders werkzaam is

$0 /+\quad 0 /+\quad 0 /+$

Reorganiseren productieproces

- kapitaalintensiteit verhogen

- functiesplitsing

Aantrekken van personeel

uit het buitenland

Stimuleren van overwerk

0

0

Reductie van productie

0

0

0

Omscholing van eigen personeel

$0 /+$

$0 /+$

0

Aannemen personeel met andere opleidingsachtergrond

Bijscholing van eigen personeel

Aannemen van te laag geschoold personeel

Aantrekken herintreder uit

"stille reserve"

0: $\quad$ Oplossing van de werkgever heeft geen effect voor doelgroep

+: $\quad$ Oplossing van de werkgever heeft mogelijk een positief effect voor de doelgroep

$0 /+$ : Oplossing van de werkgever heeft mogelijk een indirect effect voor de doelgroep

De vraag voor welke oplossing de werkgever zal kiezen hangt af van de kosten van de diverse mogelijkheden. Indien de kosten om iemand uit die andere functie "weg te kopen" lager zijn dan iemand uit het niet-direct inzetbare aanbod zodanig bij te scholen dat deze op die baanopening ingezet kan worden, dan zal het efficiënter zijn om iemand uit het niet-direct inzetbare aanbod om te scholen zodat hij of zij op die tweede plek ingezet kan worden. De vraag wat de meest efficiënte strategie zal zijn hangt af van zowel de mate waarin elders direct inzetbare mensen geworven kunnen worden, als van de vraag waar de voorkeur van de werkgever ligt en de vraag welk soort scholing goedkoper is. Dit laatste zal weer afhangen van de breedte van het beroependomein van de desbetreffende opleidingen, maar ook van de vraag hoe specifiek de opleiding dient te zijn voor een adequate uitoefening van het desbetreffende beroep. 


\section{De beschikbaarheid en inzetbaarheid van additioneel aanbod}

\subsection{Inleiding}

In paragraaf 2.2 is aangegeven dat het aanbod van schoolverlaters de komende jaren bij veel opleidingen tekort zal schieten. Hierbij is er sprake van zowel een mismatch tussen gevraagde en aangeboden kwalificaties, maar ook van een numeriek tekort. Dit impliceert dat werkgevers in toenemende mate knelpunten zullen gaan ondervinden om voldoende goed opgeleid personeel te vinden zolang ze uitsluitend werven onder schoolverlaters en kortdurig werklozen. Werkgevers zullen derhalve om moeten zien naar andere groepen waaruit zij personeel kunnen werven. Mede door de toenemende ontgroening en vergrijzing zal er een dringend beroep dienen te worden gedaan op degenen die nu niet of verminderd inzetbaar zijn op de arbeidsmarkt.

We onderscheiden in dit hoofdstuk drie groepen waaruit werkgevers hun tekort aan personeel kunnen opvullen: schoolverlaters met een verkeerde opleidingsachtergrond, langdurig werklozen en de niet-participerenden. Omdat de afstand tot de arbeidsmarkt van dit additionele aanbod groter is dan die van schoolverlaters met de 'juiste' opleidingsachtergrond, gaan we in dit hoofdstuk in paragraaf 3.2 eerst in op een factor die vaak leidt tot een geringe inzetbaarheid

van het additionele arbeidsaanbod kwalificatieveroudering. Hierbij komt ook aan de orde wat de omvang van de benodigde scholingsinspanning zou moeten zijn om iemand weer inzetbaar te maken. Vervolgens staan we in paragraaf 3.3 stil bij de vraag hoe groot de drie onderscheiden groepen feitelijk zijn en wat hun opleidingsachtergrond is. Daarnaast zal op basis van een aantal globale gegevens geprobeerd worden een indicatie te geven van de grootte van hun afstand tot de arbeidsmarkt. Tot slot zal in paragraaf 3.4 kort worden ingegaan op de vraag of werkgevers een bepaalde voorkeursvolgorde hebben voor potentiële werknemers uit de drie onderscheiden groepen.

\subsection{Kwalificatieveroudering en scholingsinspanning}

Als werkgevers hun personeel werven uit het arbeidsaanbod van schoolverlaters, is hun enige vraag of iemand beschikt over de juiste kwalificaties. Zodra zij mensen gaan aannemen uit het additionele arbeidsaanbod, krijgen zij er een probleem bij. Het is in principe mogelijk dat dit arbeidsaanbod weliswaar de juiste opleidingsachtergrond heeft, maar desondanks niet beschikt over de juiste kwalificaties. Dit kan een aantal oorzaken hebben. Het additioneel arbeidsaanbod heeft zijn opleiding al langer geleden afgerond. Hoe langer het geleden is dat een opleiding voltooid is, des te groter is de kans dat er in de tussentijd veranderingen zijn opgetreden in het curriculum van de desbetreffende opleiding. Dit kan betekenen dat hoewel een bepaalde opleiding op dit moment een goede aansluiting biedt op het beroep, 'dezelfde' opleiding voor oudere werknemers niet meer toereikend is.

Er kunnen in principe twee soorten kwalificatieveroudering worden onderscheiden: technische en economische veroudering. De eerste soort kwalificatieveroudering heeft betrekking op het 
verlies van fysieke bekwaamheden alsmede het verlies van mentale capaciteiten, waardoor men minder goed inzetbaar wordt. Een andere vorm van technische kwalificatieveroudering is atrofie. Atrofie komt voort uit het niet of onvoldoende gebruiken van kwalificaties. Dit zou zich bijvoorbeeld kunnen voordoen bij vrouwen die zich een aantal jaren hebben teruggetrokken van de arbeidsmarkt vanwege de verzorging van kinderen, bij langdurige werkloosheid, of bij het vervullen van functies die onder het opleidingsniveau van de werknemer liggen. Ook kan het zijn dat door specialisatie bepaalde kennis of vaardigheden, die iemand in een eerdere initiële opleiding heeft verworven, verloren zijn gegaan. Bij economische kwalificatieveroudering is er daarentegen geen sprake van een verandering bij de werknemers, maar daalt de waarde van hun kennis door veranderingen van buitenaf. Aan deze economische kwalificatieveroudering kan een scala aan technologische, organisatorische en arbeidsmarktontwikkelingen ten grondslag liggen (De Grip e.a, 1996).

Kwalificatieveroudering is in principe te voorkomen door mensen tijdig bij te scholen, dat wil zeggen nog voordat ze hinder ondervinden van deze veroudering. Voor het inzetten van de tot nu toe niet actieven zal er echter doorgaans scholing plaats moeten vinden om de opgetreden kwalificatieveroudering te compenseren. Als we uitgaan van de veronderstelling dat werkgevers uitsluitend mensen aannemen die ooit de desbetreffende kwalificatie verworven hebben, dan kan het in principe voldoende zijn om deze mensen een "opfriscursus" te geven. Echter ook de eerder opgedane kennis en vaardigheden die nog bruikbaar zijn, zullen voor een deel "vergeten" zijn. Om de mate van bijscholing in de vorm van een opfriscursus te bepalen, is het noodzakelijk om inzicht te krijgen in de mate van kwalificatieveroudering van de beoogde groep. Een eerste indruk van welke soort kwalificatie-veroudering er sprake is bij een persoon uit het additionele aanbod kan worden verkregen door de leeftijd van die persoon te bekijken. De gedachte daarbij is dat de opfriscursus uitgebreider dient te zijn naarmate de tijd die verstreken is sinds het voltooien van de opleiding langer is. Dit geldt waarschijnlijk zowel voor de technische kwalificatieveroudering in de vorm van het verlies van fysieke en mentale capaciteiten als voor de kans op economische kwalificatieveroudering vanwege technologische en organisatorische ontwikkelingen.

\subsection{Het additionele aanbod nader toegelicht}

Zoals in de vorige paragrafen reeds is opgemerkt, zal in deze paragraaf een overzicht worden gegeven van de omvang en de opleidingsachtergrond van drie groepen mensen waaruit werkgevers in geval van arbeidsmarkttekorten hun personeel kunnen werven. We onderscheiden hierbij de volgende groepen:

1. schoolverlaters met een opleidingsachtergrond waar een overschot voor wordt verwacht;

2. langdurig werklozen, al dan niet met de juiste opleidingsachtergrond;

3. niet-participerenden, al dan niet met de juiste opleidingsachtergrond.

De drie onderscheiden groepen hebben een verschillende positie op de arbeidsmarkt. De eerste groep bestaat uit degenen die binnen de gehele groep schoolverlaters een minder goede 
positie op de arbeidsmarkt innemen. Dit zijn voornamelijk de laaggeschoolden en de drop-outs, maar deze groep bevat ook de hoger opgeleiden die vanuit arbeidsmarktoogpunt een "verkeerde" richting gekozen hebben. De tweede groep bestaat uit degenen die reeds langer geleden hun opleiding hebben afgerond en sindsdien, ofwel nooit een positie op de arbeidsmarkt hebben kunnen verwerven, ofwel na enige tijd een betaalde baan gehad te hebben deze, al dan niet gedwongen, zijn kwijtgeraakt. Hierbij kan bijvoorbeeld gedacht worden aan ouderen die hun baan zijn kwijtgeraakt door bedrijfsreorganisaties. De laatste groep bestaat uit personen die net zoals de langdurig werklozen al langer geleden hun opleiding hebben afgerond, mogelijk gedurende kortere of langere tijd een betaalde baan gehad hebben, maar zich, al dan niet gedwongen, terug hebben getrokken van de arbeidsmarkt. Deze laatste groep is thans niet actief op zoek naar een betaalde baan. Voor een belangrijk deel bestaat deze groep uit oudere niet-participerende vrouwen die vanwege de verzorging van hun kinderen zijn gestopt met werken en nooit meer zijn her-ingetreden. Daarnaast is er een aanzienlijke groep niet-participerende ouderen die afgevloeid zijn via VUT-regelingen of arbeidsongeschiktheidsregelingen en die mogelijk opnieuw aan het werk willen en kunnen.

Deze drie groepen hebben een verschillende samenstelling en verschillende karakteristieken. Daarbij kan met name gedacht worden aan verschillen in opleidingsniveau, leeftijd, ervaring, motivatie om te werken etc. Omdat deze karakteristieken waarschijnlijk een grote invloed hebben op de mate waarin deze mensen zich daadwerkelijk op de arbeidsmarkt begeven en op de kans door een werkgever aangenomen te worden, is het van belang enig inzicht te verkrijgen in de omvang en de kenmerken van deze drie groepen. Deze karakteristieken bepalen namelijk ook in grote mate hun inzetbaarheid en dus ook hun verschillende positie op de arbeidsmarkt.

Tabel 3.1 geeft een beeld van de omvang van de drie groepen en hun opleidingsniveau. Ter vergelijking is hier ook de opleidingsstructuur van de werkzame beroepsbevolking aangegeven. Duidelijk is dat een groot deel van de werkzame beroepsbevolking een opleidingsniveau van $\mathrm{MBO} / \mathrm{LLW}$ of hoger heeft. Ook bij de langdurig werklozen en de niet-participerenden is de groep met een opleiding op het niveau van MBO/LLW het grootste. Daarentegen heeft bijna de helft van de schoolverlaters en kortdurig werklozen met een slecht arbeidsmarktperspectief slechts basisonderwijs. Van de groepen die nu niet actief zijn, is echter een veel groter deel lager opgeleid dan MBO/LLW in vergelijking met de totale beroepsbevolking. Bij de nu werkzamen is $30 \%$ lager opgeleid dan MBO/LLW, bij de schoolverlaters en kortdurig werklozen met een verkeerde opleidingsachtergrond is dat $72 \%$, bij de langdurig werklozen $47 \%$ en bij de nietparticiperenden $55 \%$. Als de mate van inzetbaarheid van dit additionele arbeidsaanbod uitsluitend afhangt van het opleidingsniveau, zal er een zeer aanzienlijke scholingsinspanning nodig zijn om de lager opgeleiden binnen deze groepen inzetbaar te maken voor de arbeidsmarkt. Aan de andere kant is er echter bijvoorbeeld in de groep niet-participerenden ook een vrij groot aantal hoger opgeleiden. Deze groep kan wellicht gemakkelijk ingezet worden op de arbeidsmarktsegmenten waarvoor grote knelpunten in de personeelsvoorziening worden verwacht. 
Zoals in de vorige paragraaf is uitgelegd, is zeker bij werknemers die al wat langer niet meer actief zijn op de arbeidsmarkt, het opleidingsniveau niet de enige factor die bepaalt of zij inzetbaar zijn op de arbeidsmarkt. Bij hen kan kwalificatieveroudering een grote rol spelen. Omdat daar geen directe gegevens over beschikbaar zijn, zullen we ons moeten behelpen met een indirecte indicator. Een maatstaf die gebruikt kan worden om aan te geven hoe de inzetbaarheid van het niet-direct inzetbare arbeidsaanbod is, is hun leeftijd. De gedachte hierbij is dat hoe ouder het aanbod, des te lager de inzetbaarheid zal worden vanwege de mogelijke kwalificatieveroudering en fysieke slijtage.

Tabel 3.1

Omvang en opleidingsniveau van het additionele aanbod en de werkzame beroepsbevolking

\begin{tabular}{|c|c|c|c|c|c|c|c|c|}
\hline & \multicolumn{2}{|c|}{$\begin{array}{r}\text { Schoolver- } \\
\text { laterş }\end{array}$} & \multicolumn{2}{|c|}{$\begin{array}{l}\text { Langdurig } \\
\text { werklozen }\end{array}$} & \multicolumn{2}{|c|}{$\begin{array}{l}\text { Niet-partici- } \\
\text { perendę, }\end{array}$} & \multicolumn{2}{|c|}{$\begin{array}{l}\text { Werkzame } \\
\text { beroepsbev }\end{array}$} \\
\hline & aantal & $\%$ & aantal & $\%$ & aantal & $\%$ & aantal & $\%$ \\
\hline $\begin{array}{l}\text { Basisonderwijs } \\
\text { VBO/MAVO } \\
\text { MBO/LLW, HAVO/VWO } \\
\text { HBO } \\
\text { WO } \\
\text { Overig }\end{array}$ & $\begin{array}{r}125.500 \\
67.500 \\
62.500 \\
9.000 \\
5.000 \\
0\end{array}$ & $\begin{array}{r}47 \\
25 \\
23 \\
3 \\
2 \\
0\end{array}$ & $\begin{array}{r}52.000 \\
69.500 \\
94.000 \\
29.500 \\
15.000 \\
500\end{array}$ & $\begin{array}{r}20 \\
27 \\
36 \\
11 \\
6 \\
0\end{array}$ & $\begin{array}{r}677.500 \\
895.500 \\
894.000 \\
273.500 \\
59.500 \\
79.000\end{array}$ & $\begin{array}{r}24 \\
31 \\
31 \\
10 \\
2 \\
3\end{array}$ & $\begin{array}{r}483.500 \\
1.321 .000 \\
2.720 .000 \\
1.097 .500 \\
458.000 \\
44.500\end{array}$ & $\begin{array}{r}8 \\
22 \\
44 \\
18 \\
7 \\
1\end{array}$ \\
\hline Totaal & 269.500 & 100 & 261.000 & 100 & 2.878 .500 & 100 & 6.125 .500 & 100 \\
\hline $\begin{array}{l}\text { a) Schoolverlaters en ne } \\
\text { een overschot wordt v } \\
\text { b) Standcijfer 1997 } \\
\text { c) Gemiddelde 1995-199 } \\
\text { Bron: CBS/ROA }\end{array}$ & $\begin{array}{l}\text { ieve uitbr } \\
\text { vacht (zie }\end{array}$ & $\begin{array}{l}\text { idings } \\
\text { tabel }\end{array}$ & $\begin{array}{l}\text { vraag } \mathrm{m} \\
2.1)\end{array}$ & & leidings & & waarvc & \\
\hline
\end{tabular}

Ook andere aspecten dan kwalificatieveroudering kunnen bij het inzetbaar maken een rol spelen: gemis aan ervaring, eventuele handicaps, etc. Arbeidsvoorziening hanteert voor de mate van inzetbaarheid van werkzoekenden een fase-indeling. Er zijn vier mogelijke fasen: Werkzoekenden in fase 1 zijn direct bemiddelbaar voor de arbeidsmarkt. Dat wil zeggen dat zij in principe zonder additionele scholing en begeleiding in staat worden geacht een baan te vinden. Werkzoekenden in fase 2 en 3 hebben respectievelijk een kort of langer scholings- of bemiddelingsprogramma nodig om hun arbeidsmarktkansen te vergroten. Werkzoekenden in fase 4 worden daarentegen (voorlopig) niet meer in staat geacht een volwaardige plaats op de arbeidsmarkt te verwerven (Van Eijs e.a., 1999). Deze fase-indeling zou hier ook gebruikt kunnen worden om de afstand van de langdurig werklozen tot de arbeidsmarkt te indiceren. Echter, voor de andere twee groepen is de fase-indeling niet bekend.

Als indicatie van de inzetbaarheid van het additionele arbeidsaanbod en daarmee als indicatie van hun inzetbaarheid, wordt in de tabellen 3.2, 3.3 en 3.4 achtereenvolgens de leeftijdsverdeling van de werkzame beroepsbevolking, de werklozen (lang- en kortdurig samen) en de niet- 
participerenden gepresenteerd.

In tabel 3.2 is te zien dat bijna $60 \%$ van de werkenden jonger is dan 40 jaar. Dit is echter niet op alle opleidingsniveau's hetzelfde. Van de ongeschoolde arbeidskrachten (alleen basisonderwijs) is een groot deel ouder dan 50 jaar. De reden hiervoor is dat de afgelopen jaren de instroom van ongeschoolden op de arbeidsmarkt aanzienlijk is afgenomen. Op WO-niveau is de jongste leeftijdsgroep kleiner dan bij de andere niveau's. De oorzaak hiervan is de (meestal) langere opleidingsduur.

Tabel 3.2

Leeftijdsverdeling werkzame beroepsbevolking naar opleidingsniveau, 1996

\begin{tabular}{|c|c|c|c|c|c|c|}
\hline Opleidingsniveau & $\begin{array}{r}15-29 \\
\%\end{array}$ & $\begin{array}{r}30-39 \\
\%\end{array}$ & $\begin{array}{r}\text { Leeftijd } \\
40-49 \\
\%\end{array}$ & $\begin{array}{r}50-59 \\
\%\end{array}$ & $\begin{array}{r}60-64 \\
\%\end{array}$ & $\begin{array}{r}15-64 \\
\%\end{array}$ \\
\hline Basisonderwijs & 21 & 24 & 32 & 22 & 2 & 100 \\
\hline VBO/MAVO & 33 & 26 & 25 & 15 & 1 & 100 \\
\hline MBO/LLW, HAVO/VWO & 33 & 30 & 24 & 12 & 1 & 100 \\
\hline $\mathrm{HBO}$ & 22 & 34 & 29 & 14 & 1 & 100 \\
\hline WO & 19 & 37 & 29 & 14 & 2 & 100 \\
\hline Overig & 14 & 29 & 38 & 17 & 1 & 100 \\
\hline Totaal & 29 & 30 & 26 & 14 & 1 & 100 \\
\hline
\end{tabular}

Bron: $\mathrm{CBS} / \mathrm{ROA}$

In tabel 3.3 is de leeftijdsverdeling van de werkloze beroepsbevolking weergegeven. De gemiddelde leeftijd van deze groep is aanzienlijk lager dan van de werkenden. In totaal is bijna $70 \%$ van hen jonger dan 40 jaar. Hierbij moet wel bedacht worden dat het hier niet alleen gaat om langdurig werklozen. Het percentage ouderen in de werkloze beroepsbevolking is juist aanzienlijk lager dan bij de werkzame beroepsbevolking. Dit is echter in belangrijke mate het gevolg van het feit dat oudere werklozen niet meer actief naar een baan hoeven te zoeken. Het grote aantal relatief jonge werklozen betekent dat een geringe inzetbaarheid vanwege kwalificatieveroudering op zichzelf geen al te groot beletsel hoeft te vormen om een werkloze in dienst te nemen. Echter, het kan wellicht zo zijn dat de werklozen (en dan met name de langdurig werklozen) een gebrek aan ervaring hebben (gemis aan on-the-job training) waardoor ze voor een werkgever relatief duur zijn.

Tabel 3.3

Leeftijdsverdeling werkloze beroepsbevolking naar opleidingsniveau, 1996

Opleidingsniveau

$\begin{array}{rrrrrr}15-29 & 30-39 & \text { Leeftijd } & & & \\ \% & \% & 40-49 & 50-59 & 60-64 & 15-64 \\ \% & \% & \% & \% & \%\end{array}$




\begin{tabular}{|c|c|c|c|c|c|}
\hline Basisonderwijs & 38 & 26 & 25 & 11 & 0 \\
\hline VBO/MAVO & 41 & 27 & 22 & 9 & 0 \\
\hline MBO/LLW, HAVO/VWO & 38 & 30 & 23 & 9 & 0 \\
\hline $\mathrm{HBO}$ & 39 & 24 & 26 & 11 & 0 \\
\hline WO & 41 & 31 & 19 & 8 & 0 \\
\hline Overig & 22 & 43 & 26 & 8 & 1 \\
\hline Totaal & 39 & 28 & 23 & 9 & 0 \\
\hline
\end{tabular}

In deze tabel is geen onderscheid gemaakt naar kort- en langdurig werklozen

Bron: $\mathrm{CBS} / \mathrm{ROA}$

Tabel 3.4

Leeftijdsverdeling niet-participerenden naar opleidingsniveau, 1996

\begin{tabular}{lrrrrrr}
\hline Opleidingsniveau & $\begin{array}{r}15-29 \\
\%\end{array}$ & $\begin{array}{r}30-39 \\
\%\end{array}$ & $\begin{array}{r}40-49 \\
\%\end{array}$ & $\begin{array}{r}50-59 \\
\%\end{array}$ & $\begin{array}{r}60-64 \\
\%\end{array}$ & $\begin{array}{r}15-64 \\
\%\end{array}$ \\
\hline Basis & 33 & 11 & 16 & 22 & 19 & 100 \\
VBO/MAVO & 38 & 13 & 15 & 22 & 13 & 100 \\
MBO/LLW, HAVO/VWO & 32 & 19 & 15 & 18 & 15 & 100 \\
HBO & 30 & 15 & 15 & 21 & 19 & 100 \\
WO & 31 & 17 & 15 & 17 & 20 & 100 \\
Overig & 65 & 15 & 8 & 8 & 4 & 100 \\
Totaal & 35 & 14 & 15 & 20 & 16 & 100 \\
\hline
\end{tabular}

Bron: $\mathrm{CBS} / \mathrm{ROA}$

In tabel 3.4 tenslotte staat de leeftijdsverdeling van de niet-participerenden. Van hen is 36 procent ouder dan 50 jaar. Deze groep bestaat voor een groot deel uit vrouwen die nooit gewerkt hebben en mensen die gewerkt hebben, maar inmiddels vanwege VUT, arbeidsongeschiktheid en pensioen niet meer actief zijn. De relatief grote groep jongeren is het gevolg van het feit dat scholieren en studenten die dagonderwijs volgen ook in deze groep zitten. Bij de niet-participerenden is het vooral de vraag waarom deze mensen zich niet aanbieden op de arbeidsmarkt. Informatie daarover is nodig om een indicatie te kunnen geven van de inspanningen die verricht moeten worden om deze mensen te kunnen werven voor de baanopeningen die in onvoldoende mate door direct-inzetbaar arbeidsaanbod vervuld kunnen worden (bijvoorbeeld betere faciliteiten kinderopvang, reïntegratie, arbeidsgehandicapten, e.d.).

\subsection{Voorkeursvolgorde van de werkgever}

In het rapport De Arbeidsmarkt naar opleiding en beroep tot 2002 (ROA, 1997a) wordt er van uitgegaan dat werkgevers bij het werven van nieuw personeel de voorkeur geven aan schoolverlaters en kortdurig werklozen. Als dit aanbod tekortschiet is er op het desbetreffende arbeidsmarktsegment sprake van een tekort aan direct inzetbare arbeidskrachten. Eventueel aanbod uit andere categorieën wordt niet in de berekeningen opgenomen, omdat er vanuit gegaan wordt dat aantrekken van "niet direct inzetbare" arbeidskrachten ex-post reacties van 
werkgevers zijn op ex-ante verwachte tekorten. De tekorten die in hoofdstuk 2 getoond zijn, zijn op deze manier bepaald.

Als we echter ook andere categorieën arbeidsaanbieders in de analyses gaan betrekken en aannemen dat er omstandigheden zijn dat werkgevers uit deze categorieën hun personeel werven, wordt het van belang om meer te weten te komen over de manieren waarop werkgevers hun vacatures vervullen en in hoeverre ze hierbij een voorkeursvolgorde tussen de diverse groepen hanteren. Dit is van belang omdat deze voorkeursvolgorde misschien wel zo is dat ook in situaties waarin er in het geheel geen sprake is van personeelstekorten werkgevers soms de voorkeur zouden geven aan bijvoorbeeld oudere, ervaren herintreders. Gemis aan ervaring bij de schoolverlaters zou in sommige situaties wel eens zwaarder kunnen wegen dan kwalificatieveroudering bij de herintreders. Voor een deel is dit voorkeursgedrag van werkgevers impliciet opgenomen in de prognoses binnen POA, omdat de ex-ante verwachte herintreders via de vervangingsvraag verdisconteerd worden.

Als we echter expliciet aan willen geven in hoeverre werkgevers hun tekorten kunnen beperken als er andere categorieën arbeidsaanbod in beschouwing genomen worden, wordt het wel van belang om te weten voor welke vacatures dit additioneel aanbod aantrekkelijk kan zijn voor een werkgever. Dit kan dan inzicht geven in enerzijds de mogelijkheden die werkgevers zien om uit andere groepen dan schoolverlaters te werven, maar het zou ook een mogelijkheid zijn om vanuit een aanbodperspectief iets te zeggen over de perspectieven voor het alternatieve aanbod. Op basis van de in hoofdstuk 2 gepresenteerde prognosecijfers kan worden geconcludeerd dat naar verwachting de vraag het aanbod van schoolverlaters zal overtreffen en dat er dus ex-post verschuivingen op zullen gaan treden in de vraag naar arbeid. Omdat er niets bekend is over de voorkeuren van werkgevers voor de diverse aanpassingsmechanismen, is het niet goed mogelijk om uitspraken te doen over de concurrentie die de diverse alternatieve aanbodgroepen van elkaar zullen ondervinden (zie ook: Borghans e.a., 1995).

Als gevolg van dit gebrek aan kennis over voorkeursgedrag van werkgevers, zullen we voor het indiceren van de knelpunten die resteren na inzet van het additionele arbeidsaanbod een paar vrij sterke aannames moeten maken. Ten eerste nemen we aan dat in principe alleen de opleidingsachtergrond bepalend is voor de mate van inzetbaarheid. Ten tweede nemen we aan dat werkgevers eerst alleen schoolverlaters en kortdurig werklozen met de juiste opleidingsachtergrond zullen aannemen, vervolgens de langdurig werklozen en daarna de niet-participerenden. Deze laatste aanname is gebaseerd op het feit dat de langdurig werklozen zich daadwerkelijk aanbieden op de arbeidsmarkt, bekend zijn bij arbeidsvoorzieningsorganisatie en daar - voor zover ze niet in fase 4 zijn ingedeeld - geschoold en begeleid worden naar de arbeidsmarkt. Deze groep is dus voor de werkgevers relatief gemakkelijk te benaderen. Pas zodra er via deze route geen mensen gevonden kunnen worden zullen werkgevers proberen om niet-participerenden te vinden die ingezet zouden kunnen worden. We gaan er van uit dat werkgevers dit pas in laatste instantie zullen doen, omdat een dergelijke actie soms grote inspanningen vergt. In dit verband kan gewezen worden op een opmerkelijk initiatief dat recentelijk door het Ministerie van Onderwijs, Cultuur en Wetenschappen is genomen om de 
stille reserve aan mensen met een onderwijsbevoegdheid op grootschalige wijze te benaderen. Het Ministerie heeft daarbij op basis van de gegevens van het pensioenfonds iedereen die in het verleden in het onderwijs heeft gewerkt aangeschreven, met het verzoek zich aan te melden bij het Ministerie, om in de groeiende tekorten aan leerkrachten te kunnen voorzien (zie ook Borghans en De Grip, 1998).

Een ander aspect waarmee mogelijk rekening dient te worden gehouden bij de vraag wie wordt aangenomen is discriminatie. Onder de laag opgeleiden en de langdurig werklozen bevinden zich relatief veel allochtonen. Daarnaast hebben langdurig werklozen vaak een stigma. In de groep van de niet-participerenden komen relatief veel vrouwen voor. Uit diverse studies is bekend dat deze genoemde groepen regelmatig geconfronteerd worden met discriminatie op de arbeidsmarkt (Van Beek, 1993). De aanwezigheid van discriminatie op de arbeidsmarkt impliceert dat bij de analyse van de mogelijkheden voor het alternatief aanbod naast de opleidingsachtergrond ook deze discriminatie aandacht verdient. Dat blijkt ook uit het gegeven dat de arbeidsmarktperspectieven voor dit aanbod, zoals die op basis van de opleidingsachtergrond bepaald zijn, nauwelijks afwijken van de perspectieven van de totale beroepsbevolking, terwijl een groot aantal personen uit deze groepen niet deelneemt aan het arbeidsproces (zie bijvoorbeeld Borghans e.a., 1998). Van Beek (1993) komt op basis van zogenoemd "vignettenonderzoek" tot de conclusie dat lager opgeleide werkzoekenden vooral geselecteerd worden op basis van eigenschappen waarop ze zelf geen invloed kunnen uitoefenen. Ditzelfde geldt voor ouderen, vrouwen en mensen met een verhoogde kans op ziekteverzuim. Hun lagere participatiegraad is voor een relatief groot deel toe te schrijven aan voorkeursgedrag van werkgevers. Van Beek komt dan ook tot de conclusie dat: "Een arbeidsmarktbeleid dat de voorkeuren van werkgevers weet te beïnvloeden wel eens meer succes zou kunnen hebben voor de positie van zwakke groepen op de arbeidsmarkt dan het bestaande beleid dat vooral gericht is op het verbeteren van de kwalificaties van werkzoekenden zonder baan" (Van Beek, $1993,183)^{4}$.

\section{Knelpunten op de arbeidsmarkt in ruime zin}

\subsection{Inleiding}

In hoofdstuk 2 is aangegeven wat de verwachte knelpunten zullen zijn in de komende jaren, als alleen schoolverlaters en kortdurig werklozen als relevant arbeidsaanbod beschouwd worden. We noemen dit hier de "knelpunten in enge zin". In het vorige hoofdstuk is aangegeven dat er bij diverse groepen die momenteel geen betaald werk hebben, mogelijkheden liggen om hen bij knelpunten in de personeelsvoorziening in te schakelen. In paragraaf 3.4 is kort stilgestaan bij de vraag in welke volgorde potentiële werknemers door werkgevers aangenomen worden. Gegeven die aannamen, kunnen we nagaan in hoeverre er ook na de inzet van het niet-direct inzetbare arbeidsaanbod knelpunten in de personeelsvoorziening resteren als deze

4. Hierbij dient opgemerkt te worden dat de werkzoekenden uit de doelgroepen wel over een vergelijkbaar kwalificatieniveau dienen te beschikken als de werkzoekenden uit de andere groepen. 
groepen ook volledig ingezet zouden kunnen worden. De knelpunten die dan resteren duiden we aan met "knelpunten in ruime zin". In paragraaf 4.2 zal aangegeven worden voor welke opleidingsniveau's er knelpunten resteren. Daarbij zal ook kort stilgestaan worden bij de noodzakelijke scholingsinspanningen. In paragraaf 4.3 zal stilgestaan worden bij de vraag in hoeverre er mogelijkheden zijn om aan te geven hoe deze resterende knelpunten opgelost zouden kunnen worden. In paragraaf 4.4 tenslotte, staan we wat uitgebreider stil bij de noodzakelijke scholingsinspanningen om de tekorten op te lossen.

\subsection{Verwachte knelpunten in ruime zin}

In hoofdstuk 2 is aangegeven voor welke opleidingssectoren er knelpunten in de personeelsvoorziening te verwachten zijn. In hoofdstuk 3 is daarna aangegeven wat het opleidingsniveau is van de drie onderscheiden groepen additioneel arbeidsaanbod. Onder de in paragraaf 3.4 gemaakte aanname dat werkgevers uitsluitend selecteren op opleidingstype en dat daarbij langdurig werklozen de voorkeur krijgen boven herintreders, kan nagegaan worden welke knelpunten door het inzetten van het arbeidsaanbod uit deze beide groepen met de juiste opleidingsachtergrond opgelost kunnen worden. De schoolverlaters met een opleidingsachtergrond waarvoor in 2002 een overschot wordt verwacht zijn hier buiten beschouwing gelaten omdat zij vanwege deze verkeerde opleidingsachtergrond door werkgevers niet als relevant aanbod beschouwd worden. In tabel 4.1 is per opleidingsniveau aangegeven wat de verwachte knelpunten in enge zin zijn. Daarnaast is aangegeven hoeveel langdurig werklozen er beschikbaar zijn per opleidingsniveau. Omdat de inzetbaarheid ook afhangt van de opleidingsrichting, is niet iedereen inzetbaar. Het blijkt dat op de niveau's tot MBO/LLW slechts de helft van de langdurig werklozen inzetbaar is, daarboven (HBO en WO) is een veel groter deel in te zetten ${ }^{5}$. Als de groep langdurig werklozen "maximaal" is ingezet, resteert er op de meeste opleidingsniveau's nog een zeer groot deel van de verwachte tekorten. Vervolgens kan nagegaan worden hoeveel mensen uit de groep niet-participerenden over een opleidingsachtergrond beschikken waarvoor nog een tekort resteert. Vanwege de grote omvang van deze groep blijkt dat er door de inzet van niet-participerenden een zeer groot deel van de tekorten opgelost zou kunnen worden. Aan de andere kant resteert er, ook bij een volledige inzet van iedereen met de juiste opleidingachtergrond (wat betreft niveau en richting) nog een tekort aan arbeidskrachten.

5. Dat dit tot nu toe niet is gebeurd, doet vermoeden dat deze langdurig werklozen op de een of andere manier een andere belemmering ondervinden om werk te vinden. 
Tabel 4.1

Verwachte knelpunten per opleidingsniveau in ruime zin in 2002

\begin{tabular}{|c|c|c|c|c|c|c|c|}
\hline \multirow[t]{2}{*}{ Opleiding } & \multicolumn{4}{|c|}{ Langdurig werklozen } & \multicolumn{3}{|c|}{ Niet-participerenden } \\
\hline & Tekort & Aantal & Inzet & $\begin{array}{r}\text { Resterend } \\
\text { tekort }\end{array}$ & Aantal & Inzet & $\begin{array}{r}\text { Resterend } \\
\text { tekort }\end{array}$ \\
\hline Basisonderwijs & - & 52.000 & - & - & 677.500 & - & - \\
\hline VBO/MAVO & 83.000 & 69.500 & 38.500 & 44.500 & 895.500 & 41.500 & \\
\hline HAVO/VWO & 261.500 & 94.000 & 43.500 & 218.000 & 894.000 & 198.500 & 19.500 \\
\hline $\mathrm{HBO}$ & 151.000 & 29.500 & 25.000 & 125.500 & 273.500 & 104.000 & 21.500 \\
\hline WO & 52.500 & 15.000 & 12.000 & 40.500 & 59.500 & 18.000 & 22.500 \\
\hline Overig & & & & & 79.000 & & \\
\hline Totaal & 551.500 & 261.000 & 119.500 & 432.000 & 2.878 .500 & 364.500 & 67.000 \\
\hline
\end{tabular}

. Aantal kleiner dan publicatiegrens $(<5.000)$

- Nihil

Bron: ROA

Bij deze "tekorten in ruime zin" past een aantal kanttekeningen. Onze aanname dat iedereen uit de beide groepen inzetbaar is, mits hij of zij over de juiste opleidingsachtergrond beschikt, is vij sterk. Maar ook de aanname dat iedereen met de juiste opleidingsachtergrond door de werkgevers ingezet kan worden is vanzelfsprekend vrij sterk. Zo blijkt er voor de berekeningen dat er bij sommige opleidingstypen zelfs als alle langdurig werklozen en alle niet-participerenden ingezet zouden worden er nog knelpunten resteren. Vanwege regionale spreiding van vraag en aanbod en het feit dat sommigen bereid of (in geval van arbeidsgehandicapten) niet in staat zijn zich op de arbeidsmarkt aan te bieden, is deze volledige inzet ongetwijfeld onhaalbaar. Een andere reden waarom (zeker) bij de niet-participerenden deze volledige inzet niet haalbaar is, wordt waarschijnlijk gevormd door het feit dat er bij deze niet-participerenden relatief veel getrouwde vrouwen zitten met een werkende partner. De lokatie of de aard van het werk van deze partner kan mogelijk een beletsel vormen om op de juiste plek ingezet te kunnen worden.

Vanwege kwalificatieveroudering of veranderingen in het curriculum dient er waarschijnlijk voor alle aan te nemen werknemers uit deze aanbodgroepen een vorm van om-, her- of bijscholing plaats te vinden. Hier ligt in feite dan ook de ruimte voor een "marktconform scholingsbeleid" om door middel van gerichte maatregelen diverse (doel)groepen te ondersteunen in hun pogingen om werk te vinden. Om alle knelpunten op te lossen dienen er waarschijnlijk nog veel meer scholingsinspanningen plaats te vinden. Uit de tabel blijkt dat zelfs indien aanbod uit de genoemde groepen en met de juiste opleiding worden ingezet er nog knelpunten in de personeelsvoorziening resteren. Er zal dus nog bij- en omscholing dienen plaats te vinden van personen met een, vanuit arbeidsmarktoogpunt, verkeerde opleidingsachtergrond van de baanopeningen waarvan het arbeidsaanbod tekortschiet.

\subsection{Indicatie van de vereiste vaardigheden}


Tot nu toe is er van uitgegaan dat alleen de opleidingsachtergrond van een werknemer bepalend is voor de inzetbaarheid op de arbeidsmarkt. Op basis van het opleidingstype van degenen die nu werkzaam zijn in bepaalde beroepen is er bepaald hoe de vraag naar bepaalde opleidingstypen verdeeld is. Zoals al in paragraaf 2.2 gesteld, hebben werkgevers een vacature voor een bepaalde functie. Voor het vervullen van deze functie is het noodzakelijk dat men over een aantal vaardigheden beschikt. Voor een werkgever is het (waarschijnlijk) dan ook van veel groter belang dat je over de gevraagde kennis en vaardigheden beschikt, dan dat iemand over een bepaald opleidingstype beschikt. Een bepaald diploma is op die manier meer een indicatie dat iemand een aantal vaardigheden heeft. De vraag van werkgevers naar een bepaald opleidingstype ligt daardoor op een aantal arbeidsmarktsegmenten waarschijnlijk veel minder vast dan bij de bovenstaande berekeningen van de aanbodtekorten is aangenomen: werkgevers zullen waarschijnlijk vrij snel zodra zij de oorsponkelijk gevraagde opleiding niet kunnen vinden uitwijken naar mensen met een andere opleidingsachtergrond, die over zoveel mogelijk van de gevraagde kennis en vaardigheden beschikken. Zeker wanneer werkgevers uiteindelijk toch moeten uitwijken naar andere opleidingstypen, komt weer de vraag boven, in hoeverre ze dat direct als een van de eerste aanpassingsmechanismen zullen doen.

Deze paragraaf zal op basis van een aantal voorbeelden ingaan op de vraag in hoeverre mensen in bepaalde beroepen moeten beschikken over bepaalde vaardigheden en in hoeverre dit overeenkomt met het opleidingstype dat ze gevolgd hebben. Om een indicatie te krijgen in hoeverre mensen uit bepaalde groepen in aanmerking zouden kunnen komen voor de vacante baanopeningen en het karakter van de daarvoor vereiste bij- of omscholing, dient eerst nagegaan te worden naar welke "vaardigheden" werkgevers op zoek zijn. Om dit in kaart te brengen moet worden nagegaan in welke beroepsgroepen degenen met een opleidingsachtergrond waarvoor een aanbodtekort wordt verwacht werkzaam zijn en welke vaardigheden er voor deze beroepen vereist zijn. Op basis van de CBS-beroepen classificatie (SBC '92) kan een elftal specifieke vaardigheden onderscheiden worden. In tabel 4.2 zijn deze specifieke vaardigheden geclusterd in zes vereiste vaardigheden. Op basis van de feitelijke verdeling van de opleidingen over de beroepen en de vaardigheden die daarvoor vereist zijn, is aan te geven welke vaardigheden verwacht worden van mensen met een bepaalde opleidingsachtergrond. Dit is vervolgens weer te gebruiken om aan te geven aan welke vaardigheden een werkgever een tekort zal krijgen als gevolg van een tekort aan aanbod met de desbetreffende opleidingsachtergrond. Dit geeft dan ook direct een indicatie over de vereiste scholingsinspanningen die noodzakelijk zijn om dit "alternatieve aanbod" inzetbaar te maken wanneer dit in onvoldoende mate over deze vaardigheden beschikt.

Dit is in feite een "omweg". Eerst wordt er op basis van de verwachte werkgelegenheidsontwikkeling in een sector een beroepenvraag bepaald. Deze wordt vervolgens herleid tot een vraag naar bepaalde opleidingstypen. Vervolgens zou nu deze vraag weer terugvertaald moeten worden naar een vraag naar beroepen en vaardigheden. Via deze route raakt er nuttige informatie verloren. Als er knelpunten in de personeelsvoorziening resteren, is het namelijk van belang om te weten welke vaardigheden er vereist worden. Deze vraag zou veel eenvoudiger te beantwoorden zijn als de knelpunten per beroep bekend zijn in plaats van per opleidingstype. 
In dat geval is het namelijk op basis van bijvoorbeeld bestaande beroepenclassificaties veel makkelijker om aan te geven welke vaardigheden er gezocht worden en wie uit de groep van het additioneel arbeidsaanbod daarvoor de geschiktste kandidaat zou zijn. Vandaar dat de hier voorgestelde aanpak gezien moet worden als de enig mogelijke zolang er geen knelpunten per beroep bekend zijn.

Omdat het te ver voert voor alle opleidingstypen waarvoor er sprake is van een tekortschietend arbeidsaanbod de vereiste vaardigheden te laten zien, volstaan we hier met een tweetal voorbeelden. Het eerste voorbeeld is een opleidingstype uit de sector MBO Dienstverlening en verpleging, namelijk de opleiding $M B O / L L W$ verpleging. Het tweede voorbeeld betreft een opleidingstype uit de sector $M B O / L L W$ economie, namelijk MBO/LLW secretariaat. In tabel 4.3 is te zien dat voor beide opleidingstypen een substantieel tekort (in enge zin) wordt verwacht.

Tabel 4.2

Clustering van specifieke vaardigheden in zes vereiste vaardigheden

1. Vakspecifieke vaardigheden:

- kwantitatieve vaardigheden;

- technische vaardigheden;

- handvaardigheden.

2. Management vaardigheden:

- leidinggevend vermogen.

3. Communicatieve vaardigheden:

- verbale vaardigheden;

- service-gerichtheid;

- persuasief vermogen.

4. Algemene vaardigheden:

- vermogen om eigen werk te ordenen en te organiseren;

- ruimtelijk voorstellingsvermogen;

- oplettendheid.

5. Kunstzinnige vaardigheden

6. Geen specifieke vaardigheid

Bron: Borghans e.a. (1997) 
Tabel 4.3

Opleidingstypen waarvoor grote knelpunten in de personeelsvoorziening worden verwacht in 2002

Opleidingstype

aantal

Tekort \%*

$\mathrm{MBO} / \mathrm{LLW}$ verpleging

34.500

28

MBO/LLW secretariaat

20.600

21

\footnotetext{
* Als percentage van de totale werkzame beroepsbevolking met de desbetreffende opleidingsachtergrond

Bron: ROA
}

Om een indicatie te geven in welke beroepsgroepen personen met de hierboven genoemde opleidingsachtergrond veelal werkzaam zijn, staan in tabel 4.4 per opleidingstype de belangrijkste beroepsgroepen (zie ROA, 1997b). Beide opleidingstypen kennen een vrij duidelijke samenhang tussen opleiding en beroep: ongeveer de helft van de mensen met deze opleidingsachtergrond komt in dezelfde beroepsgroep terecht. Als werkgevers dit tekort op willen lossen, zullen ze mensen aan moeten trekken die weliswaar niet over de juiste opleidingsachtergrond beschikken, maar toch wel over de vaardigheden die in dat betreffende beroep nodig zijn.

Tabel 4.4

Belangrijkste beroepsgroepen per opleidingstype, gemiddelde 1995-1996

Opleidingstype

$\%$

trend 1992-1996

MBO/LLW verpleging

Verplegenden en doktersassistenten

$\begin{aligned} 52 & \text { dalend } \\ 16 & \text { sterk stijgend } \\ 8 & \text { dalend } \\ 7 & \text { stijgend } \\ 23 & -\end{aligned}$

Verzorgend personeel

Therapeuten en verpleegkundigen

Ziekenverzorgenden

23

Andere beroepsgroepen

$\begin{aligned} 47 & \text { constant } \\ 14 & \text { dalend } \\ 6 & \text { constant } \\ 6 & \text { dalend } \\ 27 & -\end{aligned}$

$M B O / L L W$ Secretariaat

Boekhouders en secretaresses

Receptionisten en administratie employés

Medisch secretaresses

Commercieel employés

Andere beroepsgroepen

27

Bron: CBS/ ROA

In tabel 4.5 wordt voor de twee opleidingstypen die we als voorbeeld genomen hebben aangegeven welke vaardigheden er verwacht worden van mensen met de desbetreffende opleidingsachtergrond. Uit de tabel blijkt dat voor de hier genoemde opleidingstypen verschillende vaardigheden zijn vereist. Voor MBO/LLW verpleging geldt dat vrijwel iedereen moet beschikken over communicatieve vaardigheden en algemene vaardigheden. Opmerkelijk genoeg lijken de door het CBS onderscheiden vakspecifieke vaardigheden geen rekening te houden met de medisch-verpleegkundige vaardigheden die naar men mag aannemen vereist 
zijn in de verpleegkundige functies waarin het merendeel van degenen met deze opleidingsachtergrond werkzaam is. Voor $M B O / L L W$ secretariaat zijn de communicatieve vaardigheden de belangrijkste vereiste vaardigheden. Daarnaast is er bij dit opleidingstype ook vrij veel vraag naar vakspecifieke vaardigheden. Vooral de noodzaak om over vakspecifieke vaardigheden te beschikken betekent voor de mensen uit de hier onderscheiden groepen dat voor zover zij nog niet over deze vaardigheden beschikken, er nogal wat bij- en omscholing dient plaats te vinden De mate waarin men dient te beschikken over communicatieve en algemene vaardigheden kan namelijk tussen de opleidingstypen een grote overlap vertonen en maakt mensen dus ook buiten hun eigenlijke beroependomein inzetbaar. Daarentegen kunnen de vereiste communicatieve vaardigheden, juist voor mensen die lange tijd aan de zijlijn van de arbeidsmarkt hebben gestaan, een belangrijke drempel vormen om voor een dergelijke functie in aanmerking te komen.

Tabel 4.5

Vereiste vaardigheden per opleidingstype

\begin{tabular}{|c|c|c|c|c|c|c|}
\hline \multirow{2}{*}{ Opleidingstype } & \multicolumn{6}{|c|}{ Vereiste vaardigheden* } \\
\hline & $\begin{array}{l}1 . \\
\%\end{array}$ & $\begin{array}{l}2 . \\
\%\end{array}$ & $\begin{array}{l}3 . \\
\%\end{array}$ & $\begin{array}{l}4 . \\
\%\end{array}$ & $\begin{array}{l}5 . \\
\%\end{array}$ & $\begin{array}{l}6 . \\
\%\end{array}$ \\
\hline MBO/LLW verpleging & 15 & 3 & 93 & 60 & 0 & 1 \\
\hline MBO/LLW secretariaat & 53 & 6 & 59 & 8 & 0 & 1 \\
\hline
\end{tabular}

* De nummers van de vereiste vaardigheden verwijzen naar de clustering in tabel 4.2 Bron: ROA

\section{$M B O / L L W$ verpleging}

Zoals reeds eerder is aangegeven is de kwalificatieveroudering van degenen die reeds lang langs de kant van de arbeidsmarkt staan een factor die mogelijk een belemmering kan vormen voor een terugkeer naar betaald werk. Functie-inhoudelijke kwalificatieveroudering is voor een belangrijk deel het gevolg van technologische en organisatorische ontwikkelingen (De Grip, Van Loo en De Steur, 1999). In de beroepsgroepen waarin mensen met opleidingsachtergrond $M B O / L L W$ verpleging veelal werkzaam zijn, is het risico op kwalificatieveroudering door technologische en organisatorische ontwikkelingen echter beperkt. Dit heeft derhalve gunstige implicaties voor herintreders en langdurig werklozen met deze opleidingsachtergrond, er zal in het algemeen weinig aanvullende scholing vereist zijn.

Een tweede factor die mogelijk een belemmering kan vormen voor een terugkeer naar betaald werk is het werken onder slechte arbeidsomstandigheden. De beroepsgroepen waarin personen met de opleiding $M B O / L L W$ verpleging veelal terecht komen worden gekenmerkt door het relatief vaak voorkomen van slechte arbeidsomstandigheden. Hierbij kan zowel gedacht worden aan het kracht zetten tijdens het werk als aan het werken in ploegendiensten (ROA, 1998b). 
Indien de belastende arbeidsomstandigheden ertoe leiden dat er een grote uitstroom uit de betreffende beroepsgroepen plaats vindt, kan dit gevolgen hebben voor het oplossen van de knelpunten voor dit opleidingstype. Mensen die vanwege deze belastende arbeidsomstandigheden (al dan niet gedwongen) zijn uitgetreden uit een van de beroepsgroepen kunnen moeilijk beschouwd worden als potentieel aanbod om de tekorten op te lossen.

\section{MBO/LLW secretariaat}

Voor het opleidingstype MBO/LLW secretariaat worden tot het jaar 2002 eveneens grote knelpunten in de personeelsvoorziening verwacht. De problemen die werkgevers hebben om in hun personeelsbehoefte te voorzien, scheppen daardoor mogelijkheden voor het niet direct inzetbare arbeidsaanbod. Het werk in de beroepsgroepen waarin schoolverlaters met deze opleidingsachtergrond terecht komen, wordt echter in sterkere mate beïnvloed door de voortschrijdende technologische ontwikkelingen (ROA, 1998b). De informatisering van het werk in de secretariële beroepen heeft vanzelfsprekend belangrijke implicaties voor herintreders en langdurig werklozen. Voor de herintreders en langdurig werklozen met een opleidingsachtergrond $M B O / L L W$ secretariaat en die willen werken in een van de betreffende beroepsgroepen zal een aanzienlijke bijscholing nodig zijn om de verouderde kwalificaties weer op peil te brengen. Daarnaast kan het ook het geval zijn dat veel langdurig werklozen met een opleidingsachtergrond MBO/LLW secretariaat, juist zijn uitgestroomd omdat zij de technologische vooruitgang niet konden "bijbenen". In dat geval vormen zij geen potentieel aanbod meer om de tekorten bij dit opleidingstype op te lossen.

Binnen de beroepen waarin degenen met een opleiding MBO/LLW secretariaat werkzaam zijn is er doorgaans geen sprake van belastende arbeidsomstandigheden. De arbeidsomstandigheden zullen derhalve geen belemmering vormen voor herintreders of arbeidsgehandicapten met een opleiding MBO/LLW secretariaat.

\subsection{Scholingsinspanningen}

In de vorige paragraaf is aangegeven dat de vraag van werkgevers primair gericht is op het aantrekken van arbeidskrachten met bepaalde kwalificaties. Om na te gaan welke mensen er aangenomen worden, is het van belang om na te kunnen gaan wie over de meeste door de werkgever gevraagde kwalificaties beschikt en dus tegen de laagste scholingskosten door deze werkgever kan worden ingezet.

Als werkgevers gaan werven uit de hier onderscheiden groepen additioneel arbeidsaanbod, zal, ook als er geen mensen met de juiste opleidingsachtergrond beschikbaar zijn op de arbeidsmarkt, een werknemer gevonden moeten worden die in ieder geval beschikt over een groot deel van de vereiste kwalificaties of het vermogen heeft deze binnen redelijke termijn en tegen redelijke kosten te verwerven. Ditzelfde geldt voor de mate waarin men geconfronteerd wordt met belastende arbeidsomstandigheden: er moeten mensen gevonden worden die binnen dat type werk kunnen functioneren. 
Als werkgevers geconfronteerd worden met een tekortschietend arbeidsaanbod voor een bepaald opleidingstype zullen ze op zoek moeten naar arbeidskrachten met een qua kwalificatieprofiel verwante opleidingsachtergrond. Als er mensen aangenomen worden met een verkeerde opleidingsachtergrond volgt de noodzakelijke scholingsinspanning uit de mate van scholing die nodig is om mensen om- of bij te scholen tot de benodigde opleidingsrichting of het benodigde -niveau. Deze inspanning kan aanzienlijk zijn. Hierbij dient echter rekening te worden gehouden met het feit dat opleiden voor een specifieke baanopening niet altijd de beste strategie hoeft te zijn. Immers, programma's waarin personen uit de drie groepen heel specifiek opgeleid worden tot de kennis en vaardigheden waarvoor een ex-ante vraagoverschot bestaat hebben twee risico's. Het eerste risico is dat de lange termijn positie van de personen uit deze groep daardoor niet beter hoeft te worden, omdat de scholingsinspanningen gericht zijn op het verwerven van kwalificaties waarmee men relatief weinig uitwijkmogelijkheden op de arbeidsmarkt heeft, of onderhevig zijn aan een sterke conjunctuurgevoeligheid van de werkgelegenheid. Het andere risico is dat de werkgevers hun tekorten opvullen door arbeidskrachten met de juiste opleidingsachtergrond die in andere beroepsgroepen werkzaam zijn. Er zou in dat geval om- of bijgeschoold moeten worden tot een kennis- en vaardighedenniveau waarmee men inzetbaar is op plaatsen die vacant worden als gevolg van de baan-baan mobiliteit die ontstaat als gevolg van deze aanpassingsprocessen.

In alle gevallen waarbij scholing noodzakelijk is, zal bedacht moeten worden dat mensen tijdens hun studie heel vaak voor het maximaal haalbare opleidingsniveau gekozen hebben. Deze trend is de laatste jaren steeds sterker geworden. Er kan daardoor niet tot willekeurig elk niveau bijgeschoold worden. Daarbij dient ook rekening te worden gehouden met de mate waarin mensen zich willen laten om- of bijscholen. Dit geeft aan dat werkgevers, ook als ze bereid zijn om werknemers met de verkeerde opleidingsachtergrond aan te nemen, zich toch meestal zullen moeten richten op het arbeidsaanbod met een verwante opleidingsachtergrond.

Bij de benodigde scholingsinspanning kan eveneens niet worden voorbijgegaan aan het gemak waarmee mensen uit de verschillende groepen geworven kunnen worden en de mate van discriminatie waarmee zij te maken zullen krijgen. Indien blijkt dat lager opgeleide allochtonen voornamelijk vanwege hun afkomst niet aangenomen worden, dan is om- of bijscholing nauwelijks effectief. Ditzelfde geldt voor langdurig werklozen. Indien zij werkloos zijn vanwege andere aspecten dan alleen hun opleiding, zoals bijvoorbeeld de eerder beschreven stigmatisering, zullen ook zij nauwelijks gebaat zijn bij additionele scholing. Als laatste wordt er op gewezen dat ook het aanbodgedrag van de groepen bepalend kan zijn voor het gemak waarmee men inzetbaar gemaakt kan worden. Schoolverlaters hebben doorgaans bewust gekozen voor een bepaalde opleiding. Als zij vrij snel na het voltooien van hun opleiding geconfronteerd worden met de keuze omscholing of werkloosheid, ligt het voor de hand dat een deel van hen kiest voor een periode van werkloosheid, in afwachting van een baan die wel past bij hun opleiding. Er is dan sprake van zogenoemde "zoekwerkloosheid". In dat geval zal een deel van de oplossing niet liggen in het omscholen van schoolverlaters, maar in het omscholen van werkenden met de betreffende opleidingsachtergrond. Als deze dan "doorschuiven" naar een ander beroep, ontstaan er baanopeningen voor de schoolverlaters. Maar ook 
hier geldt weer dat er veel meer informatie nodig is over zowel de vraag naar arbeid als het aanbod daarvan. Met name het aanpassingsgedrag van werkzoekenden moet hiervoor nader geanalyseerd worden. Een eerste aanzet hiertoe is gegeven in Marey en Borghans (1998).

Voor de niet-participerenden dient een onderscheid te worden gemaakt tussen de bewust nietparticiperenden en zij die wel willen werken, maar waar geen vraag naar is. Als de eerste categorie er toe overgehaald moet worden om, ondanks de bewuste keuze niet op de arbeidsmarkt te participeren, weer te gaan werken, moet er eerst nagegaan worden wat de belangrijkste reden was om te stoppen met werken. Het merendeel van deze groep heeft ooit besloten te stoppen met werken vanwege de opvoeding van de eigen kinderen. Het feit dat ze nu niet meer werken kan twee verklaringen hebben. Het kan zijn dat deze vrouwen zich niet meer aanbieden op de arbeidsmarkt, maar het kan ook zo zijn dat ze wel zoeken naar werk maar dit niet kunnen vinden omdat het gecombineerd moet worden met zorgtaken. In beide gevallen lijkt scholing niet de belangrijkste drempel naar de arbeidsmarkt te zijn, maar zijn het veel meer de ontbrekende randvoorwaarden die de gang naar de arbeidsmarkt belemmeren (zie bijvoorbeeld Plantenga, 1993). Pas zodra hierin verandering gebracht is, zal men een eventuele mogelijkheid om weer op de arbeidsmarkt te gaan participeren aangrijpen. Voor de mensen die wel willen werken, maar niet aan het werk kunnen, is het duidelijk dat er sprake is van een verminderde inzetbaarheid. Als bekend is, bijvoorbeeld op basis van gegevens zoals in hoofdstuk 3, wat deze verminderde inzetbaarheid veroorzaakt, kan daar actie op worden ondernomen. Voor niet-participerenden is scholing derhalve waarschijnlijk maar een deel van de maatregelen die nodig zijn om ze weer in te zetten op de arbeidsmarkt. Ook faciliteiten als kinderopvang e.d. en faciliteiten die de reïntegratie van arbeidsgehandicapten mogelijk maken spelen hier een belangrijke rol.

\section{Samenvatting en conclusies}

De arbeidsmarkt naar opleiding en beroep tot 2002 laat ontwikkelingen zien die wijzen op een sterke omslag in de arbeidsmarktsituatie. De komende jaren wordt voor een groot aantal opleidingstypen knelpunten in de personeelsvoorziening verwacht. Het gevolg hiervan is dat werkgevers in toenemende mate op zoek moeten naar additioneel arbeidsaanbod vanuit groepen die op dit moment niet actief zijn op de arbeidsmarkt.

In hoofdstuk 2 van dit werkdocument is aangegeven wat de verwachte knelpunten op de arbeidsmarkt zullen zijn tot 2002. Hierbij is uitgegaan van de aanname dat werkgevers hun baanopeningen vervullen door schoolverlaters aan te nemen. Met andere woorden, het aantal schoolverlaters in de komende jaren zal te klein zijn om in de verwachte vraag naar arbeidskrachten te voorzien. Om de toekomstige knelpunten in de personeelsvoorziening (gedeeltelijk) op te lossen moeten werkgevers daarom gaan werven uit het additioneel aanbod. In dit werkdocument zijn drie groepen onderscheiden:

1. schoolverlaters met een opleidingsachtergrond waar een overschot voor wordt verwacht;

2. langdurig werklozen, al dan niet met de juiste opleidingsachtergrond; 
3. niet-participerenden, al dan niet met de juiste opleidingsachtergrond.

Voor een deel zijn dit ook de groepen met een minder sterke positie op de arbeidsmarkt; enerzijds door het (mogelijk) te kort schieten van hun opleiding of ervaring, anderzijds door bijvoorbeeld discriminatie of stigmatisering.

Behalve het aannemen van mensen uit groepen die voorheen niet direct als arbeidsaanbod beschouwd werden, kunnen werkgevers ook op andere manieren hun tekorten op proberen te lossen. Werkgevers hebben namelijk ook andere mogelijkheden om in het geval van knelpunten in de personeelsvoorziening de openstaande vacatures op te vullen. Dit kan leiden tot uiteenlopende aanpassingsprocessen op de arbeidsmarkt. In hoofdstuk 2 is daar een aantal van besproken. Op basis van de nu bekende gegevens is het echter zeer moeilijk aan te geven in welke mate werkgevers zich van de verschillende aanpassingsprocessen zullen bedienen.

In hoofdstuk 3 is een overzicht gegeven van de beschikbaarheid en inzetbaarheid van de groepen die als additioneel aanbod worden beschouwd. Hierbij is met name aandacht besteed aan de vraag in hoeverre deze groepen te maken hebben gehad met kwalificatieveroudering. Vanwege deze veroudering zal namelijk in de meeste gevallen een vorm van her-, bij- of omscholing dienen plaats te vinden om dit additioneel aanbod inzetbaar te maken op de arbeidsmarkt. In hoeverre deze scholing dient plaats te vinden is voor de hier onderscheiden groepen en personen verschillend.

Schoolverlaters zijn een doorgaans vrij homogene groep, die afgezien van de opleidingsachtergrond, relatief weinig onderlinge verschillen vertonen. De nu in de analyses betrokken groepen hebben al een arbeidsmarktgeschiedenis achter de rug en zijn dus niet als een homogene groep te beschouwen. Om aan te geven welke groepen ingezet kunnen en mogelijk ook zullen worden, zal er veel meer dan tot nu toe bekend moeten zijn over de voorkeursvolgorde die werkgevers hanteren tussen potentiele werknemers met een verschillende achtergrond. Voor sommige vacatures zullen zij de voorkeur geven aan een schoolverlater boven een herintreder, maar in andere gevallen zullen zij mogelijk de voorkeur geven aan een herintreder. Het is dus heel moeilijk om ex-ante aan te geven welke personen uit het additioneel aanbod waar worden aangenomen.

In hoofdstuk 4 van dit werkdocument wordt ondanks deze problemen toch een poging gedaan om aan te geven in hoeverre verwachte knelpunten voorkomen kunnen worden door het additioneel arbeidsaanbod als relevant arbeidsaanbod te beschouwen. Hierbij is de veronderstelling gemaakt dat werkgevers alleen werven op basis van de opleidingsachtergrond van het additionele arbeidsaanbod en dat langdurig werklozen makkelijker te werven zijn dan nietparticiperenden. Op deze manier kunnen de knelpunten in ruime zin in kaart worden gebracht. Het blijkt uit de cijfers in dit hoofdstuk dat zelfs als deze twee groepen additioneel aanbod worden ingezet, er op verschillende segmenten van de arbeidsmarkt nog knelpunten in de personeelsvoorziening resteren.

Ondanks het feit dat er knelpunten in de personeelsvoorziening blijven bestaan, blijft er aan 
de andere kant een vrij groot potentieel aan arbeidskrachten bestaan dat niet ingezet kan worden. In hoofdstuk 4 is een aanzet gegeven om na te gaan in welke mate er mogelijkheden bestaan om de knelpunten op te lossen. Er moet daarvoor nagegaan worden naar welke vaardigheden werkgevers op zoek zijn. Vervolgens kan dan worden nagegaan wie uit de nietactieven over deze vaardigheden beschikt, of deze relatief eenvoudig aan kan leren. Op deze manier moet het mogelijk zijn om aan te geven op wat voor manier de resterende knelpunten opgelost kunnen worden.

Bij een dergelijke aanpak doet zich echter een probleem voor van de huidige methodiek. Deze methodiek geeft namelijk de knelpunten per opleidingstype weer, en op basis daarvan kan niet worden aangegeven welke personen uit de verschillende groepen additioneel aanbod voor welke vacature worden aangenomen. De vraag naar arbeid per beroep wordt in de huidige analyses namelijk vertaald naar een vraag naar een bepaald opleidingstype. Als er knelpunten resteren, is het echter van belang om te weten welke vaardigheden er vereist worden. Deze vraag zou veel eenvoudiger te beantwoorden zijn als de knelpunten per beroep bekend zijn in plaats van per opleidingstype. In dat geval is het namelijk op basis van bijvoorbeeld bestaande beroepenclassificaties veel makkelijker om aan te geven welke vaardigheden er gezocht worden en wie uit de groep van het additioneel arbeidsaanbod daarvoor de geschiktste kandidaat zou zijn.

Op basis van dit werkdocument kunnen dan ook twee conclusies getrokken worden. Ten eerste is het van groot belang dat er veel duidelijker dan tot nu toe inzicht komt in de processen die er op de arbeidsmarkt spelen. Hoe passen werkgevers en werkzoekers hun gedrag aan als er zich tekorten voordoen en wat zijn de concurrentieverhoudingen tussen de diverse groepen potentiële werknemers. Ten tweede moet er veel meer dan tot nu toe het geval geweest is, aandacht geschonken worden aan de vraag welke vaardigheden er door de werkgevers gezocht worden. In dat kader is het van belang dat er op een betrouwbare manier knelpunten per beroep bepaald kunnen worden.

\section{Literatuur}

Beek, K.W.H. van, (1993), To be hired or not to be hired, the employer decides. Relative chances of unemployed job-seekers on the Dutch labor market, Proefschrift, Universiteit van Amsterdam, Amsterdam. 
Borghans, L., A. de Grip, E. Willems, (1995), Herijking ROA-Informatiesysteem Onderwijs-Arbeidsmarkt, ROA-R-1995/1, Maastricht.

Borghans, L., A. de Grip, M. van Smoorenburg, (1998), Measuring Skills Shortages,ROA-R-1998/4E, Maastricht.

Borghans, L., J. Delmee, P. Marey en J.D. Vlasblom, (1998), Toekomstverkenning arbeidsmarkt en scholing tot 2007, Ministerie van Sociale Zaken en Werkgelegenheid, Den Haag.

Borghans L., A. de Grip, W. Smits en H. Zuurbier (1997), Het beroependomein van opleidingen, ROA-R1997/2, Maastricht.

Borghans L. en A. de Grip, (1998), De werking van de arbeidsmarkt voor verpleegkundigen en verzorgenden, ROA, Maastricht, mimeo.

Grip, A. de, L. Borghans en W. Smits, (1998), Future Developments in the Job Level and Domain of Highskilled Workers, in: Heijke H. en L. Borghans. (eds), Towards a Transparent Labour Market for Educational Decisions, Aldershot, blz. 21-56.

Grip, A. de, J. van Loo en M. de Steur (1999), Scholing van werkenden, ROA-R-1999/3, Maastricht.

Marey P. en L. Borghans, (1998), Adjustments Processes on the Labour Market: A random coefficient Approach, paper gepresenteerd op de NAKE Research Day, Amsterdam.

Plantenga, J., (1993), Een afwijkend patroon, honderd jaar vrouwenarbeid in Nederland en (West)-Duits land, Proefschrift, Groningen.

Researchcentrum voor Onderwijs en Arbeidsmarkt, (1997a), De arbeidsmarkt naar opleiding en beroep tot 2002, ROA-R-1997/7, Maastricht.

Researchcentrum voor Onderwijs en Arbeidsmarkt, (1997b), De arbeidsmarkt naar opleiding en beroep tot 2002, Statistische Bijlage, ROA-R-1997/7b, Maastricht.

Researchcentrum voor Onderwijs en Arbeidsmarkt, (1998a), Werkgelegenheid en scholing 1997, ROA-R1998/1, Maastricht.

Researchcentrum voor Onderwijs en Arbeidsmarkt, (1998b), Werkgelegenheid en scholing 1997, Statistische Bijlage, ROA-R-1998/1B, Maastricht.

Vlasblom, J.D., A. de Grip en J. van Loo, (1997), Arbeidsmarktperspectieven voor meisjes en allochtonen, ROA-R-1997/9, Maastricht. 